УДК 333.1:574(571.56)

JEL L 90, M 21

DOI 10.31375/2226-1915-2020-3-5-11

Гіві Гавардашвілі доктор технічних наук, професор orcid id: 0000-0001-5289-3830 e-mail: givi_gava@yahoo.com

Мартін Вартанов доктор економічних наук, професор Інститут водного господарства ім. Цотне Мирихулава Грузинського технічного університету, Тбілісі, Грузія

\section{МЕТОДИ РОЗРАХУНКУ СОЦІАЛЬНО- ЕКОНОМІЧНИХ ЗБИТКІВ ВІД ПОВЕНЕЙ}

Анотація. Обсяги затоплених водоймах 3 висотними гідротехнічними спорудами, в числі висотних земляних гребель, часто складають від декількох сотень мільйонів до десятків мільярдів кубометрів і навіть більше.

У даній статті описана методика розрахунку сочіально-економічних втрат для об'сктів, затоплених і зруйнованих хвилею иунамі в разі можливої аварії на висотному гідровузлі.

Аварії на висотних дамбах супроводжуються утворенням хвиль типу иунамі з високою кінетичною енергією. Під час свого руху вони завдають великої шкоди різним відвідним спорудам і часто викликають руйнування комунікаційних, спортивних, туристичних або портових споруд, а також, на жаль, людські жертви. При визначенні ефективності та доиільності будівництва необхідно визначити прогнозовану величину можливого збитку в разі аварії греблі.

Сочіально-економічний збиток, нанесений проривом греблі, можна розглядати як суму збитку, нанесеного людською жертвою, руйнуванням гідравлічних і промислових об'єктів, а також сільського господарства, водного господарства, лісового господарства та комунального господарства.

Ключові слова: повінь, гребля, сочіально-економічні збитки.

(C) Gavardashvili Givi, Vartanov Martin, 2020

\section{УДК 333.1:574(571.56) \\ JEL L 90, M 21 \\ DOI 10.31375/2226-1915-2020-3-5-11}

\author{
Гиви Гавардашвили \\ доктор технических наук, профессор \\ orcid id: 0000-0001-5289-3830 \\ e-mail: givi_gava@yahoo.com \\ Мартин Вартанов \\ доктор экономических наук, профессор \\ Институт водного хозяйства им. \\ Цотне Мирихулава Грузинского технического \\ университета, Тбилиси, Грузия

\section{МЕТОДЫ РАСЧЕТА СОЦИАЛЬНО- ЭКОНОМИЧЕСКОГО УЩЕРБА ОТ НАВОДНЕНИЙ}

Аннотация. Объемы затопленных водоемов с высотными гидротехническими сооружениями, в том числе высотных земляных плотин, часто составляют от нескольких сотен миллионов до десятков миллиардов кубометров и даже больше.

В данной статье описана методика расчета сочиально-экономических потерь для объектов, затопленных и разрушенных волной иунами в случае возможной аварии на высотном гидроузле.

Аварии на высотных дамбах сопровождаются образованием волн типа иунами с высокой кинетической энергией. Во время своего движения они наносят большой ушерб различным отводным сооружениям и часто вызывают разрушение коммуникачионных, спортивных, туристических или портовых сооружений, а также, к сожалению, человеческие жертвы. При определении эффективности и иелесообразности строительства необходимо определить прогнозируемую величину возможного ущерба в случае аварии плотины.

Социально-экономический ущерб, нанесенный прорывом плотины, можно рассматривать как сумму ущерба, нанесенного человеческой жертвой, разрушением гидравлических и промышленных объектов, а также сельского хозяйства, водоемного хозяйства, лесного хозяйства и коммунального хозяйства.

Ключевые слова: наводнение, плотина, сочиально-экономический ущерб. 
UDK 333.1:574(571.56)

JEL L 90, M 21

DOI 10.31375/2226-1915-2020-3-5-11

\title{
METHODS TO CALCULATE THE SOCIAL-ECONOMIC DAMAGE CAUSED BY FLOODS
}

\author{
Givi Gavardashvili \\ Doctor of Technical Sciences, Professor \\ orcid id: 0000-0001-5289-3830 \\ e-mail:givi_gava@yahoo.com \\ Martin Vartanov \\ Doctor of Economics Sciences, Professor \\ Tsotne Mirtskhulava Water Management Institute \\ of Georgian Technical University, Tbilisi, Georgia
}

Abstract. The volumes of the water reservoirs flooded with high-rise hydrotechnical facilities, including high-rise earth dams, often range from several hundreds of millions to tens of billions of cubic meters and even more.

The present paper describes the methodology to calculate the social-economic losses for the facilities flooded and destroyed by a tsunami-type wave in case of a possible high-rise hydraulic facility accident.

The social-economic damage caused by a dam failure can be viewed as a sum of damage caused by human victim, destruction of hydraulic and industrial facilities and agriculture, pond economy, forestry and communal services.

Keywords: flood, dam, social-economic damage.

\section{ACKNOWLEDGMENT}

The research was financial supported by Shota Rustaveli National Science Foundation of Georgia, Grant Project \# FR17_615 «Theoretical research of vulnerable infrastructure security risk during formation of predictable disasters»».

\section{INTRODUCTION}

In case of a high-rise hydraulic facility accident, tsunami-type waves are formed (See Fig. 1), which inflict a great damage to the tailrace facilities.

The dynamic parameters of a tsunami-type wave depend on the volume of water $\left(W_{0}\right)$ in the water reservoir formed by a high-rise dam, which is calculated by the following expression $[3 ; 4]$

$$
W=\frac{H_{B} S_{B}}{3}, \text { mln. } \mathrm{m}^{3}
$$


Where: $H_{B}$ is the water depth at a normal dam flooding height $(\mathrm{m}) ; S_{B}$ is the area of the water level in the water reservoir $\left(\mathrm{mln} . \mathrm{m}^{3}\right)$;
In case of a flood, the wave velocity (V) in the facility tailrace is calculated by the following formula [5-8]

$$
V=V_{0}\left(H_{1} / H_{0}\right)^{2 / 3}, \mathrm{~m} / \mathrm{sec}
$$

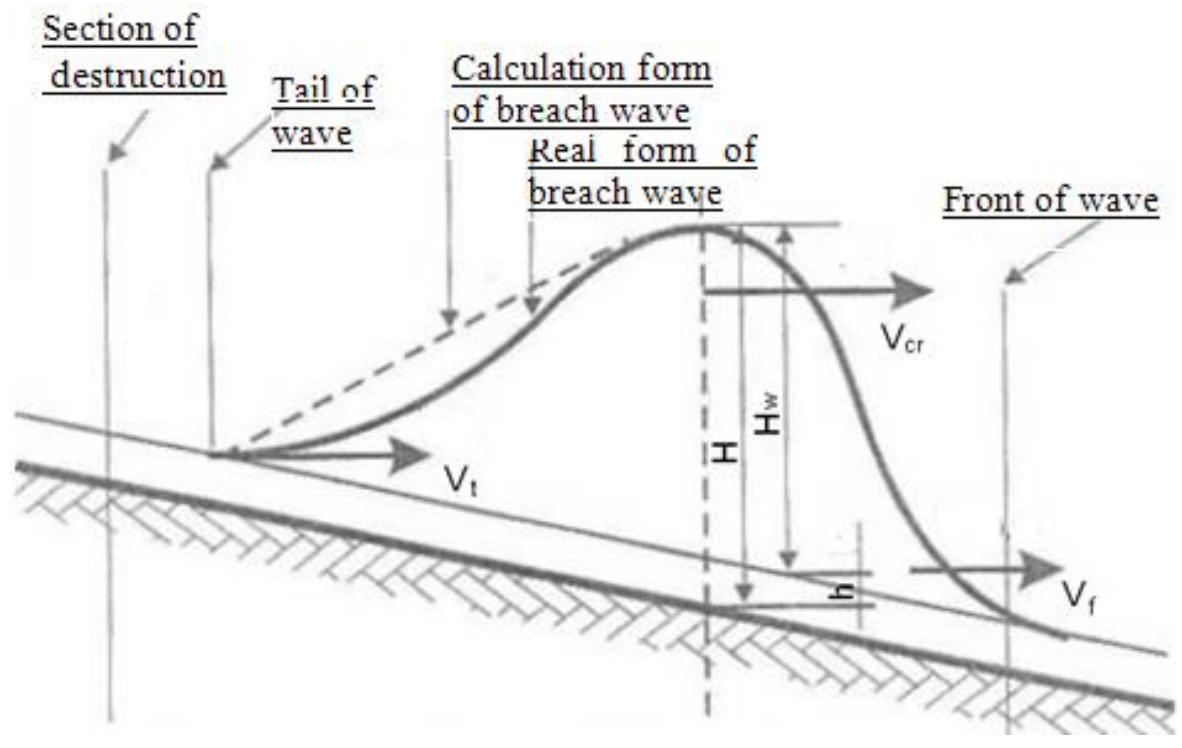

Fig. 1. Longitudinal profile of a tsunami-type wave

Degree of dam destruction $\left(E_{\mathrm{p}}\right)$ is calculated by formula $[5 ; 8]$

$$
E_{p}=\frac{F_{B}}{F_{0}} .
$$

Where: $F_{B}$ is the area of the bank rupture $\left(\mathrm{m}^{2}\right) ; F_{0}$ is the surface area $\left(\mathrm{m}^{2}\right)$.

In addition, when specifying the efficiency and feasibility of construction, it is necessary to determine the predicted value of possible damage in case of a dam accident. In this case, the losses can be presented as the sum of damage inflicted immediately to the hydraulic structures and losses in industry, forestry, communal services and objects with different functions and human victims $[1 ; 10 ; 11]$.

The above-listed technical requirements must also be met by the existing state of high-rise dams, as there are facilities with various functions located in the dam tailrace and when assessing their risks, the damage of all objects, which may get damaged or fail due to the dam accident must be considered. 


\section{THE CALCULATE \\ THE SOCIAL-ECONOMIC DAMAGE}

Let us consider the new methodology developed by us to calculate the loss for each item $[4 ; 9]$.

1. The loss caused by the destruction of the hydraulic facility is determined by formula

$$
D_{h}=\sum_{1}^{3} K_{i}=K_{1}+K_{2}+K_{3} .
$$

Where: $K_{l}$ is the balance value of the demolished part of the hydraulic facility; $K_{2}-$ is the capital expenses of restoration of the demolished part of the hydraulic facility; $K_{3}-$ is the repair costs of the demolished part of the hydraulic facility.

\section{by formula}

2. The industrial loss is calculated

$$
D_{m}=\sum_{i=1}^{7} d_{i}=d_{1}+d_{2}+d_{3}+d_{4}+d_{5}+d_{6}+d_{7} \text {. }
$$

Where: $d_{l}$ is the loss caused by the industrial equipment; $d_{2}$ is the loss caused by the demolition of industrial and non-industrial premises; $d_{3}$ is the repairs costs of the damaged industrial equipment and premises; $d_{4}$ is the repairs costs of the damaged non-industrial equipment and premises; $d_{5}$ is the loss caused by the destruction of raw materials and materials, as well as stored goods; $d_{6}$ is the losses caused by the reduced labor productivity; $d_{7}$ is the loss caused by the reduction in production and is calculated by formula

$$
d_{7}=\sum_{i=1}^{t} \frac{d_{i 7}}{(1+\alpha)^{t}} .
$$

Where: $(1+\alpha)^{t}$ is the discounting ratio; $t$ is the duration of the restoration period (year).

\section{Loss of agricultural and forest} economies

The given type of loss covers the destruction of agricultural and forest plots, loss of cattle, destruction of industrial and non-industrial premises and agricultural machines and equipment, etc. and is calculated by formula

$$
D_{s m}=D_{m c}+D_{m x}+D_{t k} .
$$

Where: $D_{m c}$ is the losses in the field of crop growing; $D_{m x}-$ is the losses in the field of cattle-breeding, including pond economy; $D_{t k}$ is the loss of forestry.

The losses of plant growing include the losses of both, annual and perennial crops and the agricultural expenses.

\section{Expenses to restore the fertility of plots of field \\ Expenses to restore the fertility of} the plots of field cover the expenses to restore and repair the industrial funds. The losses in crop-growing are calculated by formula 


$$
D_{m c}=\frac{d_{m c 1}+d_{m c 2}+\ldots+d_{m c k}}{(1+\alpha)^{1}}+\frac{d_{m c 1}+d_{m c 2}+\ldots+d_{m c k}}{(1+\alpha)^{2}}+\ldots+\frac{d_{m c 1}+d_{m c 2}+\ldots+d_{m c k}}{(1+\alpha)^{t}}
$$

Where: $d_{m c k}$ is the loss of type $k$ in cropgrowing; $(1+\alpha)^{t}-$ is $t$ discounting ratio $t$ is the period needed to restore the agriculture (year).

\section{Losses in cattle-breeding}

The losses in cattle-breeding cover the losses related to cattle death, costs to restore their livestock population, costs of repairs and restoration of the buildings and premises of a cattle-breeding complex, costs of repairs and restoration of the pond economy and costs of sanitary-epidemiological measures. The losses of cattlebreeding are calculated by formula

$$
D_{m x}=\frac{d_{m x 1}+d_{m x 2}+\ldots+d_{m x k}}{(1+\alpha)^{1}}+\frac{d_{m x 1}+d_{m \times 2}+\ldots+d_{m x k}}{(1+\alpha)^{2}}+\ldots+\frac{d_{m x 1}+d_{m x 2}+\ldots+d_{m x k}}{(1+\alpha)^{t}}
$$

Where: $d_{m x k}$ is the loss of type $k$ in cattlebreeding; $(1+\alpha)^{t}$ is the discounting ratio ( $t$ is the time needed to restore agriculture (year)).

\section{Losses in forestry}

The losses in forestry are resulted from the destruction and reduced productivity of forest massifs and costs of recovery of the destroyed forest. The forestry loss is calculated by the following formula:

$$
D_{t k}=\frac{d_{t k 1}+d_{t k 2}+\ldots+d_{t k k}}{(1+\alpha)^{1}}+\frac{d_{t k 1}+d_{t k 2}+\ldots+d_{t k k}}{(1+\alpha)^{2}}+\ldots+\frac{d_{t k 1}+d_{t k 2}+\ldots+d_{t k k}}{(1+\alpha)^{t}}
$$

Where $d_{m x k}$ is the losses of type $k$ in forestry; $(1+\alpha)^{t}$ is the discounting ratio ( $t$ is the time needed to restore forestry, years).

\section{Losses in communal services}

The losses in communal services $\left(D_{k m}\right)$ is the sum of costs needed to clean the flooded areas and restore the infrastructure $\left(d_{k m l}\right)$, to restore destroyed watersupply facilities $\left(d_{k m 2}\right)$, to rehabilitate and repair public transport $\left(d_{k m 3}\right)$, to rehabilitate and repair destroyed living and public buildings and premises $\left(d_{k m 4}\right)$ and to restore destroyed green plantings $\left(d_{k m 5}\right)$

$$
D_{k m}=\sum_{i=1}^{n} d_{k m i}
$$

Where $d_{k m i}$ is the loss of type $i$ of the communal services.

\section{Losses caused by human victim}

Generally, a human life is invaluable, but in the given context, the losses caused by a human victim can be approximately calculated by means of insu-rance amount

$$
D_{a}=n * C \text {. }
$$

Where $n$ is the number of victims; $\mathrm{C}$ is the maximum insurance amount of human life. 
DEVELOPMENT OF MANAGEMENT

AND ENTREPRENEURSHIP METHODS

ON TRANSPORT, № 3 (72), 2020
РОЗВИТОК МЕТОДІВ

УПРАВЛІННЯ ТА ГОСПОДАРЮВАННЯ

НА ТРАНСПОРТІ, № 3 (72), 2020

\section{CONCLUSION}

The accidents of high-rise dams are followed by the formation of tsunami-type waves with high kinetic energy. As they move, they inflict a great damage to various tailrace facilities and often cause the destruction of communication, sports, touristic or port facilities and unfortunately, human victim as well.

The social-economic damage caused by a dam failure can be viewed as a sum of damage caused by human victim, destruction of hydraulic and industrial facilities and agriculture, pond economy, forestry and communal services.

\section{REFERENCE}

1. Ayyub, B.M. (2009). Rick Analysis in Engineering and Economics. Chapman\&Hall/CRC. A CRC press Company, Boca Raton London, New York, Washington, D.C., $571 p$.

2. Checklist for contingency planning for accidents affecting transboundary waters, with introductory guidance. UNICE, UNITED NATIONS, New York and Geneva, 2016, $51 \mathrm{p}$.

3. Gavardashvili, G.V., Ayyub, B.M., Sobota, J., Bournaski, E. \& Arabidze, V. (2009). Simulation of Flood and Mud Flow Scenarios in Case of Failure of the Zhinvali Earth Dam International Symposium (With the support of UNESCO) on FLOODS AND MODERN METHODS OF CONTROL MEASURES. 23-28 September 2009, Tbilisi, Georgia, pp.148-163.

4. Gavardashvili, G. \& Vartanov, M. (2008). Evaluation of the social-economic damage of the forest massifs burnt during the military actions of August, 20008 in Georgia and soil anti-measures over the mountain slopes. Collection of Works of Water Management Institute \#64, pp. 48-51.

5. Gavardashvili, G.V. (2011). Safety measures of mountain landscapes during natural and technogenic catastrophes, Tbilisi, Publishing House «Universali», p. 237.

6. Gavardashvili, G.V. (2011). Forecasting of Erosion and Debris Flow Processes for the Energy Supply and Transport Corridors of Georgia Using the Theory of Reliability and Risk. First International Conference on Vulnerability and Risk Analysis and Management (ICVRAM), April 11-13, University of Maryland, USA, pp. 813-820 (publishing ASCE).

7. Gavardashvili, G.V. (2018). Forecasting the Security of the Local People in Village Nakra of Mestia Region (Georgia) Against Floods and Mudflows // Environments, ITS, UK, pp. 13-24 www.itspoa.com/jurnal/envi. 
DEVELOPMENT OF MANAGEMENT

AND ENTREPRENEURSHIP METHODS

ON TRANSPORT, № 3 (72), 2020
РОЗВИТОК МЕТОДІВ

УПРАВЛІННЯ ТА ГОСПОДАРЮВАННЯ

НА ТРАНСПОРТІ, № 3 (72), 2020

8. Gavardashvili, G.V., Kukhalashvili, E., Supatashvili, T., Iremashvili, I., Bziava, K. \& Natroshvili, G. The Calculation of Maximal and Average Speed of Debris Flow Formed as a Result of Outstretched Water Wave on the Land Dam of Zhinvali. International Conference on Construction and Environmental Engineering. WASET, Barcelona, Spain, June 11-12, 2019, pp. 1029-1032.

9. Kovalev, V.V. (1998). Methods to assess investment projects. Moscow, "Finances and Statistics», ISBN 5-279-01871-6.

10. Mirtskhoulava, Ts.E. (2003). Hazards and Risk (at some water and other systems. Types, Analysis, Assessment). 2 Books. Tbilisi, «Metsniereba», 807 p. [in Russian].

11. Natishvili, O.G. \& Gavardashvili, G.V. (2019). Calculation of Impact Action of a Coherent Mudflow Current in the Wave Motion Mode on a Transverse Structure. $9^{\text {th }}$ International Scientific and Technical Conference, Modern Problems of Water Management, Environmental Protection, Architecture and Construction. Tbilisi, pp. 210-214.

Article received 27.08.2020

Reference a JournalArtic: Gavardashvili, Givi \& Vartanov, Martin. (2020). Methods to calculate the social-economic damage caused by floods. Development of management and entrepreneurship methods on transport. 3 (72), 5-11. DOI 10.31375/2226-1915-2020-3-5-11. 